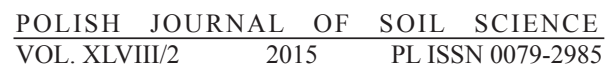

DOI: $10.17951 / \mathrm{pjss} / 2015.48 .2 .139$

Soil Physics

\author{
PAWEŁ SOWIŃSKI*, MIROSŁAW ORZECHOWSKI* \\ SŁAWOMIR SMÓLCZYŃSKI*, BARBARA KALISZ*
}

\title{
PARTICLE-SIZE DISTRIBUTION IN SOILS IN VARIOUS GROUND MORAINE CATENAS IN THE MASURIAN LAKELAND
}

Abstract. The aim of the work has been to compare the particle-size distribution in the soils of two catenas located in two mesoregions in the Masurian Lakeland and formed within two phases of the Vistula Glaciation. The studied catenas are located in the Olsztyn Lakeland within the Pomeranian phase (Pierwagi catena) and the Mragowo Lakeland within the Poznan phase of the Vistula Glaciation (Linowo catena). The soil sequence in the catenas was as follows: Haplic Cambisol (Eutric) - Mollic Gleysol (Colluvic) - Umbric Gleysol - Limnic Sapric Histosol. In 34 soil samples collected from genetic horizons, the particle size was analysed as well as sedimentological and granulometric indices were calculated.

The soils of the two studied catenas (except for two soil horizons) had similar texture of sandy loam. The translocation of the silt fraction occurred down the slope. The soils located in land depressions contained $40 \%$ more of the silt fraction than the soils on the summit of the slope. This process was not noted for the clay fraction. The studied soils were weakly and very weakly sorted and were variously sedimented in different environments. The soils formed from postglacial loam had a smaller mean grain diameter (up to $0.051 \mathrm{~mm}$ ) than the soils formed from colluvial deposits. Among the studied granulometric fractions, fine and very fine sand prevailed.

The particle-size distribution is one of the main physical parameters in mineral soils. The percentage share of the sequential fractions and sub-fractions influences soil physical and chemical properties and may be used to describe some soil physical properties $[3,7,10]$.

In the case of the young glacial landscape with a diversified relief, modification of the primary texture occurs as a result of anthropogenic denudation.

* Assoc. Prof. P. Sowiński. P, DSc., Assoc. Prof. M. Orzechowski, DSc., Assoc. Prof. S. Smólczyński, DSc., Assoc. Prof. Barbara Kalisz DSc.; Department of Soil Science and Land Reclamation, University of Warmia and Mazury in Olsztyn, Plac Łódzki 1 3, 10-957 Olsztyn, Poland. 
Translocation of soil material down the slope is induced and accelerated by human activity and influences the modification of soil cover and soil properties $[4,9,16,18,20]$. In the studied catenas, the particle-size distribution may inform/suggest about the conditions of the transport and sedimentation of parent material as well as about further translocation of soil material down the slope $[7,13,17,19,22]$.

The changes in the particle-size distribution in the soils of the young glacial agricultural landscapes are permanent and slow and/or rapid if they are initiated by man. The impoverishment of surface soil horizons in silt and clay may occur. Those fractions may accumulate in lower parts of the slope and in closed depressions $[17,18,19]$. Therefore, the texture of those very young sediments is a derivative of the texture of surrounding soils [1].

\section{STUDY AREA}

The particle-size distribution was studied in two mesoregions in the Mazurian Lakeland: the Olsztyn Lakeland and the Mraqgowo Lakeland (Fig. 1), in the landscape of the lakeland hummocks - Pierwagi and Linowo catenas.

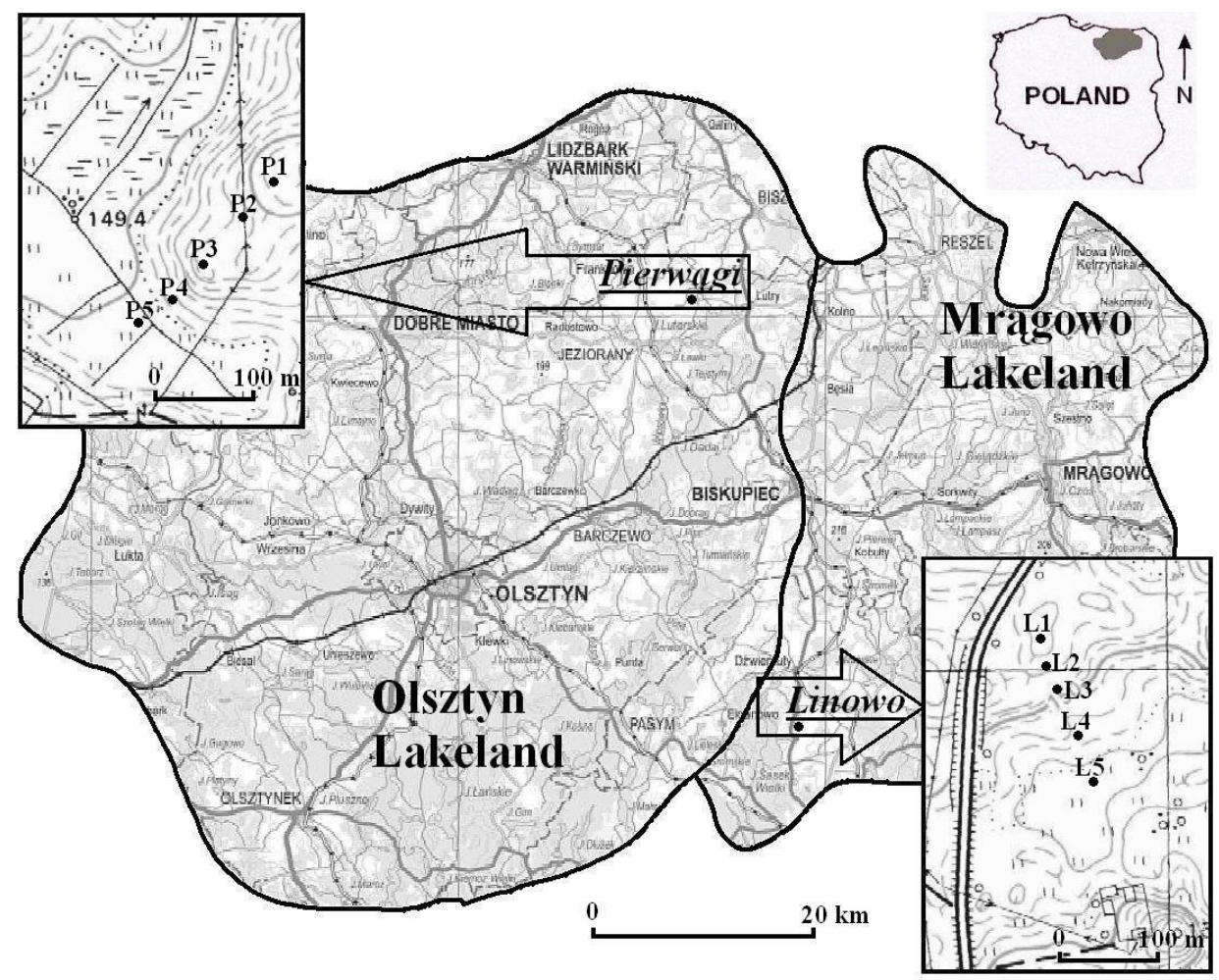

Fig. 1. Location of studied sites. 
Pierwagi catena is located in the northern part of the Olsztyn Lakeland, within the Pomeranian phase of the Vistula Glaciation, with the coordinates: $54^{\circ} 00^{\prime} 57.7^{\prime \prime} \mathrm{N}, 20^{\circ} 49^{\prime} 58.8^{\prime \prime}$ E. That catena has the following soils sequence: Haplic Cambisol (Eutric) (P1) - Mollic Gleysol (Colluvic) (P2, P3) - Limnic Sapric Histosol (P4, P5) [10].

Linowo catena is located in the southern part of the Mragowo Lakeland, within the oldest phase (Poznan) of the Vistula Glaciation, with the coordinates: $53^{\circ} 39^{\prime} 25.7^{\prime \prime} \mathrm{N}, 20^{\circ} 57^{\prime} 16.0^{\prime}$ " E. It has the following soils sequence: Haplic Cambisol (Eutric) (L1) - Mollic Gleysol (Colluvic) (L2, L3) - Umbric Gleysol (L4, L5) [9].

\section{METHODS}

The studied soil catenas were situated from the summit of the slope towards a depression. Ten soil profiles were described and 34 soil samples were collected. In the laboratory the soil texture was analysed by means of the hydrometer method of Bouyoucos modified by Cassagrande and Prószyński with the separation of sand sub-fractions by dry sieving [2]. The soil texture classes were determined according to the classification of the Polish Society of Soil Science [11], consistent with the USDA classification system. The results of the particle-size analysis (percentage share of fractions) were analysed by means of the SIEWCA computer program [2] in order to draw granulometric curves and calculate sedimentological indices of Folk and Ward [13]. For the purposes of the granulometric analyses, the following indices were used: mean diameter (Md in $\mathrm{mm}$ ), standard deviation ( $\delta 1$ in phi), skewness (Sk1 in phi) and kurtosis (KG in phi). Granulometric indices were also calculated, determining the relative proportions between thicker (less mobile) grain size fractions [6, 12]. Those parameters may be helpful in predicting the initial homogeneity or heterogeneity of soil material: $\mathrm{A}=(0.25-0.10 \mathrm{~mm}) /(0.50-0.25 \mathrm{~mm}), \mathrm{B}=(0.25-0.10$ $\mathrm{mm}) /(1.00-0.50 \mathrm{~mm}), \mathrm{C}=(0.25-0.05 \mathrm{~mm}) /(0.50-0.25 \mathrm{~mm}), \mathrm{D}=(0.25-0.02$ $\mathrm{mm}) /(1.00-0.25 \mathrm{~mm}), \mathrm{E}=(0.50-0.05 \mathrm{~mm}) /(1.00-0.50 \mathrm{~mm})$. Sites, originally homogenous in sedimentological terms, have similar values of granulometric indices (A-E). In contrast, the differentiated ratios indicate genetically heterogeneous soil material.

The soils were classified according to the WRB system [5], and horizon symbols - according to the Polish Soil Classification System [8].

\section{RESULTS AND DISCUSSION}

The results of the analysis of the particle-size distribution as well as sedimentological and granulometric indices are presented in the Tables 1-4. 


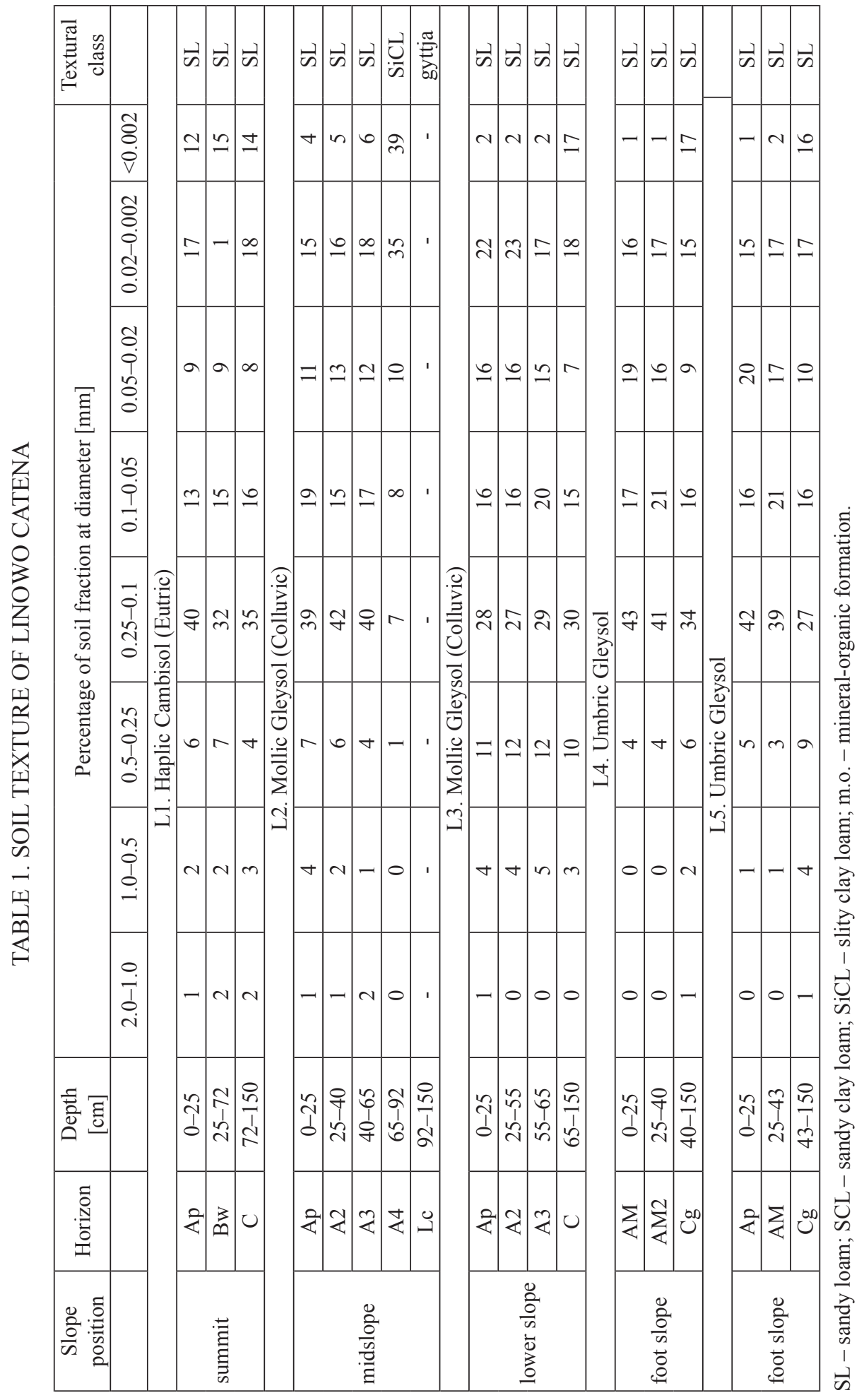




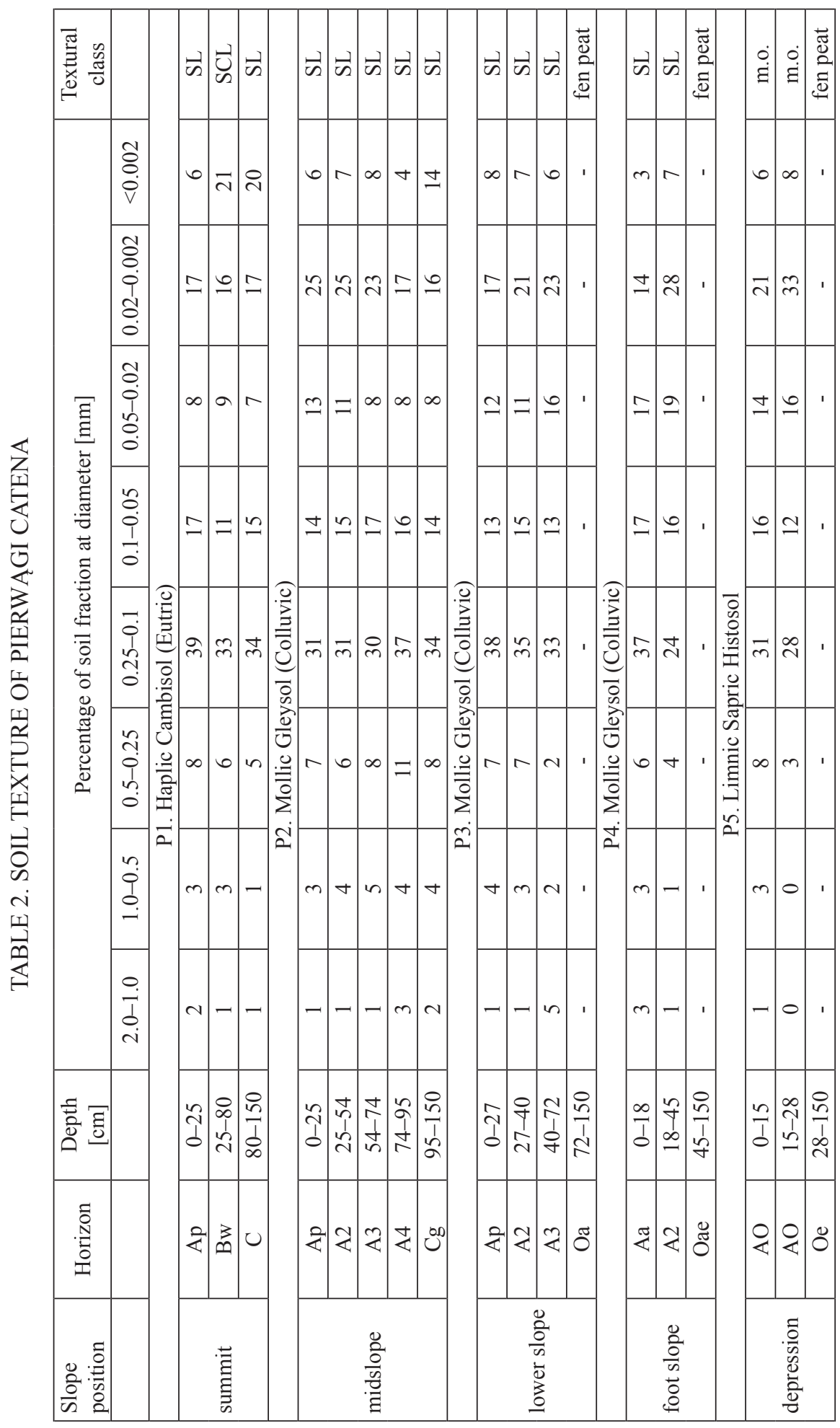




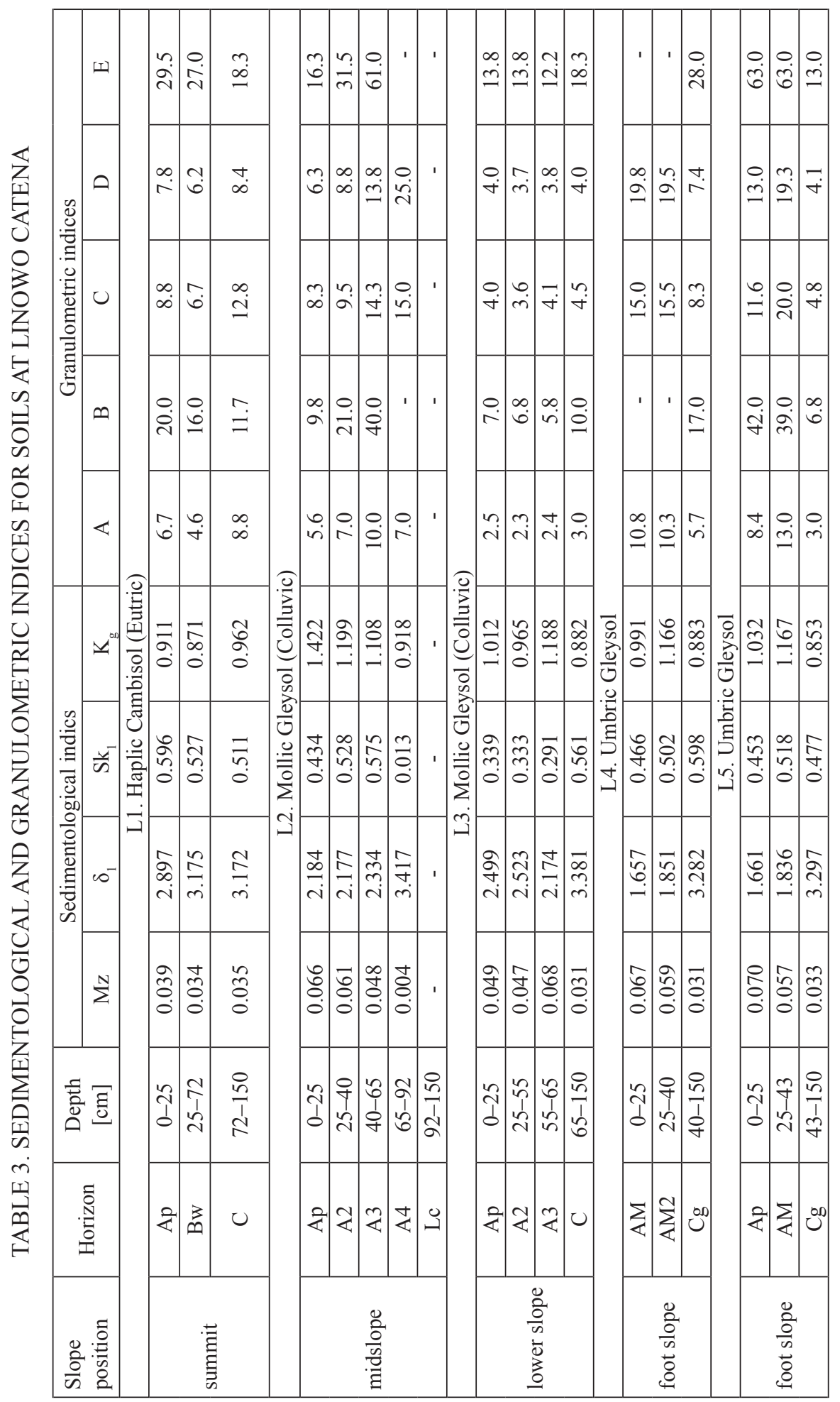




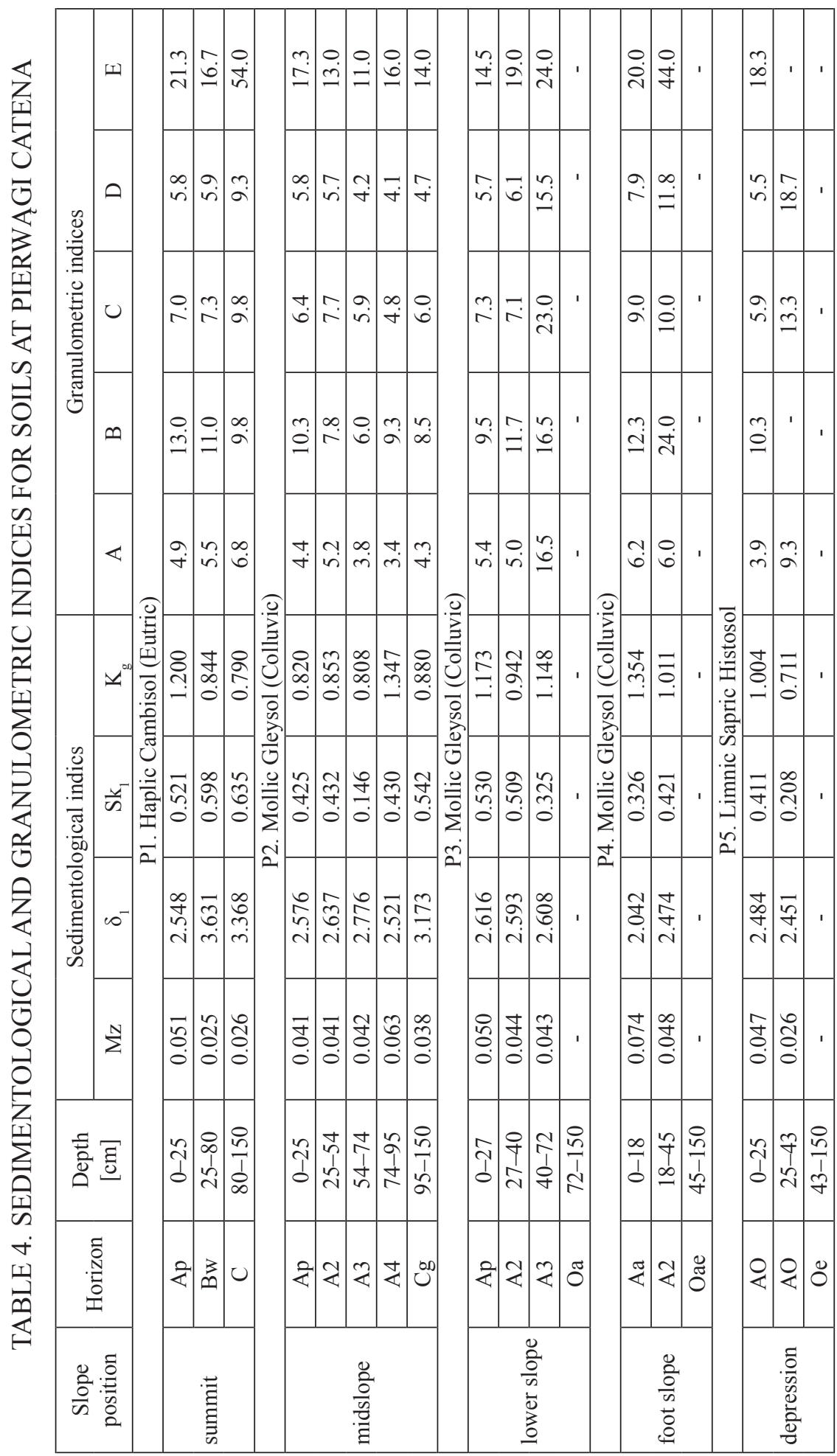


The soils of both studied catenas, located at the summit of the slope, had the texture of sandy loam (Fig. 2 and 3]. The Bt horizon in P1 soil only had the texture of sandy clay loam. The studied soils contained $24-27 \%$ of the silt fraction. The content of the clay fraction varied. The translocation of the clay fraction down the soil profile was noted. That process is common and is related to the luviation of soil material (even colluvial) $[1,7]$. In the case of Linowo catena, the soils contained $12-15 \%$ of the clay fraction. In the case of Pierwagi catena, in P1 soil, more sand fraction was found in humus horizon, which contained merely $6 \%$ of the clay fraction. Bt and $\mathrm{C}$ horizons contained $21 \%$ and $20 \%$ of the clay fraction, respectively. The translocation of the clay fraction down the soil profile was confirmed by the mean grain diameter. In Ap horizon of the studied soil, the index of $\mathrm{Mz}$ amounted to $0.051 \mathrm{~mm}$ whereas in $\mathrm{Bw}$ and $\mathrm{C}$ horizons it reached $0.025 \mathrm{~mm}$ and $0.026 \mathrm{~mm}$, respectively (Tab. 4). In L1 soil, mean grain diameter did not vary in the soil profile and amounted to $0.034-0.035 \mathrm{~mm}$. The standard deviation index $\left(\delta_{1}\right)$ amounted to 2.548-3.631, which suggested very weak sorting of soil material in the soils located at the summit of the slope in the case of both of the studied catenas. The skewness index $\left(\mathrm{Sk}_{1}\right)$ was positive in the studied soils, which suggested the asymmetric right-hand distribution. The skewness index ranged within 0.511-0.598, suggesting the dominance of finer fractions in the studied soils. The soils located at the summit of the slope had platykurtic granulometric distribution. Leptokurtic granulometric distribution was only found in Ap horizon of lessive soils (L1) (Tab. 4).
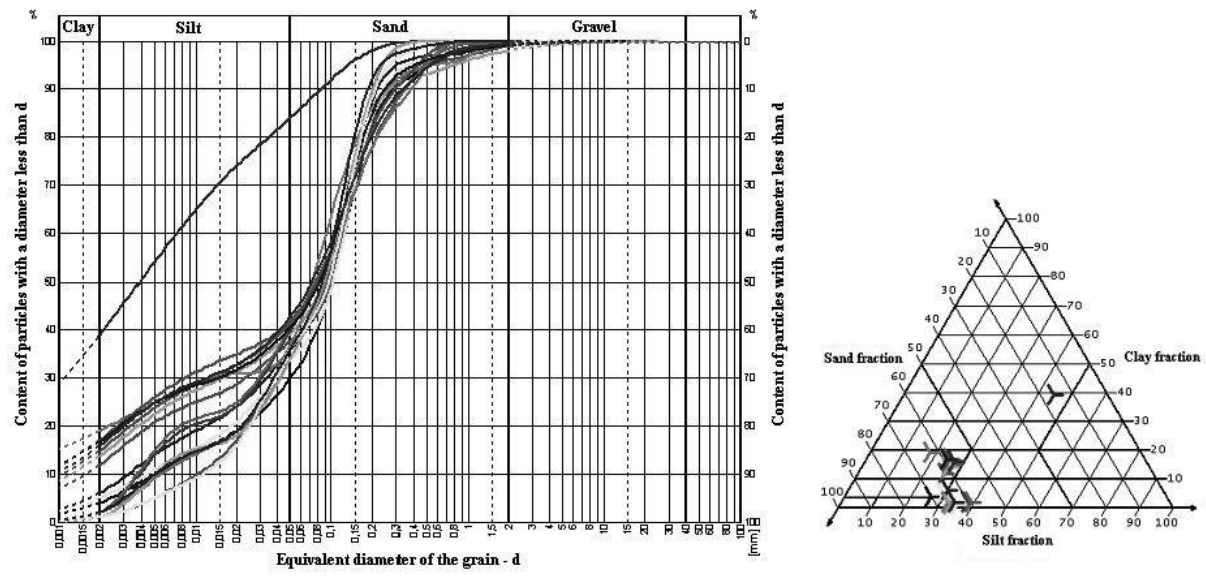

Fig. 2. Cumulative curves of genetic horizons and diagram of soil texture at Linowo catena. 

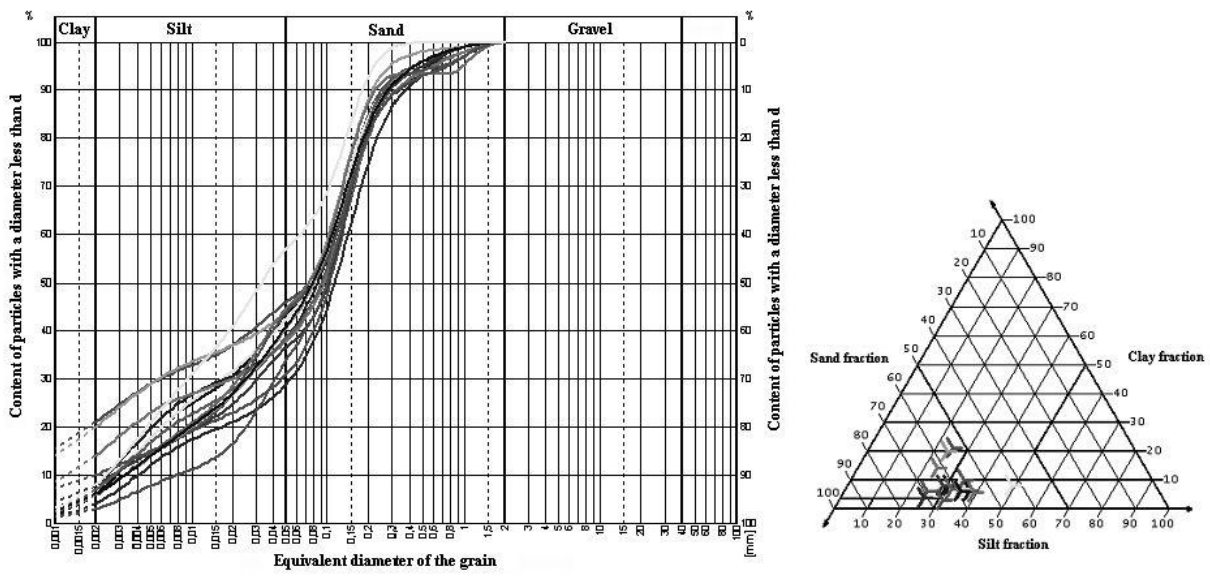

Fig. 3. Cumulative curves of genetic horizons and diagram of soil texture at Pierwągi catena.

The parent material of all the studied soils had sandy loam texture and similar amounts of the silt (24-27\%) and clay (14-20\%) fractions (Fig. 2 and 3). The granulometric distribution in $\mathrm{C}$ horizons, which is glacial loam, is testified by the sedimentological indices. In parent material, mean grain diameter amounted to $0.026-0.038 \mathrm{~mm}$, which meant it was weakly sorted. The $\delta_{1}$ index exceeded 3.0. The $\mathrm{C}$ horizons had the right-hand asymmetric distribution $\left(\mathrm{Sk}_{1}\right.$ $-0.477-0.635)$ and platykurtic granulometric distribution. The values of those indices were typical for postglacial loams $[6,12,14]$.

Higher differences were noted in surface horizons of soils located lower at the slope. Deluvial sediments located at those parts of the slope were related to the translocation and accumulation as a result of anthropogenic denudation. Those processes usually lead to the unsorting of the primary soil material and accumulation of finer fractions in lower parts of the slope and/or in depressions $[1,17,18]$. Most genetic horizons had sandy loam texture. They contained more of the silt (25-47\%) and less clay (1-8\%) fraction than the eroded soils and parent material. A4 horizons in L2 soil only had silty clay loam texture and increased amount of silt (45\%) and clay (39\%) as compared to other soil horizons. The studied deluvial surface horizons in P2-4 and L2-3 soils had higher mean grain diameter than soils at the summit of the slope. The Mz index reached $0.074 \mathrm{~mm}$. The lowest mean grain diameter was found in A4 horizon in L2 soil $-0.004 \mathrm{~mm}$. The studied soil horizons were very weakly sorted. P3-4 soils were better sorted. The $\delta_{1}$ index for those soils amounted to less than 2. The skewness index was positive, which suggested the right-hand asymmetric distribution. In the analysed soil horizons, the kurtosis was most varied. It had platy-, mezo and leptokurtic distribution (Fig. 2 and 3). Catenal or profile relationships for such a high variety were not found in this case. 
In order to determine the homogeneity of soil material, granulometric indices were calculated (Table 3 and 4). They determine mutual relations between less mobile (coarser) granulometric fractions $[6,12]$.

The A index amounted to 3.9-9.3 in the soils in the case of Pierwagi catena. The A index reached 16.5 only in A3 horizon in P3 soil. Similar values of A index were noted in the soils in the case of Linowo catena (2.3-13.0). In this case, the increase in the amount of fine sand down the slope, as compared to coarse sand, was noted. The B index in the soils in the case of Linowo catena (5.8-42.0) was more diversified than in the soils in the case of Pierwagi catena (6.0-24.0). In the case of both catenas, the increase in the value of B index towards the centre of depression was noted. Similar tendencies were found for $\mathrm{C}, \mathrm{D}$ and $\mathrm{E}$ indices. In the soils in the case of both catenas, sub-fractions of fine and very fine sand prevailed. The soils that were formed through anthropogenic denudation may have had more heterogenous soil material [17]. This process is better manifested in the soils of Linowo catena, especially in the soils located at lower parts of the slope (L4 and L5). Colluvial soils (L2, L3, P2, P3) located in the middle and lower parts of the slope contained more homogenous material than eroded soils.

\section{CONCLUSIONS}

1. The soils of the studied catenas had homogenous texture - of sandy loam, with the dominance of fine and very fine sand.

2. In the studied soils, the silt fraction was translocated down the slope. The soils located in the depressions, contained $40 \%$ more of the silt fraction than the soils at the summit of the slope. A similar process was not reported for the clay fraction.

3. The studied soils were weakly and very weakly sorted and had various sedimentological environments. The soils formed from glacial loams had smaller mean grain diameter (up to $0.051 \mathrm{~mm}$ ) than the soils formed from deluvial deposits.

4. Physical and geographical unit and the phase of the Vistula Glaciation did not influence the differences in granulometric and sedimentological indices of the studied soils.

\section{ACKNOWLEDGEMENT}

The paper was financially supported by the Project of the National Science Centre No N310 776040 . 


\section{REFERENCES}

[1] B i e n i e k B.: Acta Acad. Agricult. Tech. Olst. Agricultura, 64, Suppl. B, 1997.

[2] BJB software house: Siewca 3.0, Poznań, 2010.

[3] B r o g o w s k i Z., K w a s o w s k i W., M a d y n i a k R.: Soil Science Annual, 65(4), 139, 2014.

[4] De Alba S., Lind st or m M., S chu ma cher T.E., M a lo D.D.: Catena, 58,77, 2004.

[5] IUSS Working Group - FAO: WRB-World Reference Base for soil resources. World Soil Resources Report No. 103FAO, Rome, 2006.

[6] K o b i e r s k i M.: Roczn. Glebozn., 61(3), 65, 2010.

[7] K o m i s a r e k J., S z a ł a t a S.: Nauka Przyroda Technologie, Melioracje i Inżynieria Środowiska, 2(2), 1, 2008.

[8] Komisja V Genezy, Klasyfikacji i Kartografii Gleb PTG: Roczn. Glebozn., 62(3), 2011.

[9] O r z e c h ow s k i M.: Sorptive properties of alluvial and deluvial soils in various landscapes of North-Eastern Poland. Soil of Chosem Landscape. (Ed. B. Bieniek). Dep. Land Raclamation and Environ. Manag., Univeristy of Warmia and Mazury in Olsztyn, 21, 2009.

[10] Orzechowski M., S mólczyński S., Dług os z J., Poźni ak P.: Soil Science Annual, 65(2), 72, 2014.

[11] Polskie Towarzystwo Gleboznawcze: Roczn. Glebozn., 60(2), 5, 2009.

[12] Pru sink i e w i c z Z., P r o s z e k P.: Roczn. Glebozn., 41(3/4), 5, 1990.

[13] R a c in ow ski R., S z c zy pek T., Wa ch J.: Prezentacja i interpretacja wyników badań uziarnienia osadów czwartorzędowych. Wyd. Uniwersytetu Śląskiego, Katowice, 2001.

[14] Ró ż ań s k i S.: Roczn. Glebozn. 61(3), 100, 2010.

[15] Ryżak M., B a rt mińs ki P., B i e ga n o w s k i A.: Acta Agrophysica, Rozprawy i Monografie, 4, 2009.

[16] S i n k i e w i c z M.: Rozwój denudacji antropogenicznej w środkowej części Polski północnej. UMK, Toruń, 1998.

[17] S molska E.: Znaczenie spłukiwania w modelowaniu stoków młodoglacjalnych. UW, Warszawa, 2005.

[18] S ow iński P., L e mk owska B.: Toposequence and soil properties in the landscape of ground moraine of Olsztyn Lakeland. Soil of Chosem Landscape. (Ed. B. Bieniek). Dep. Land Raclamation and Environ. Manag., Univeristy of Warmia and Mazury in Olsztyn, 21, 2009.

[19] S o w iń s k i P.: Polish J. Soil Sci., 47(1), 51, 2014.

[20] Ś w i t o n i a k M.: Catena, 116, 173, 2014.

[21] Wy s o c k a - C z u b a s z e k A.: Polish J. Soil Sci., 45(1), 69, 2012.

[22] Z a g ó r s k i Z.: Roczn. Glebozn., 47(Supl.), 125, 1996.

\section{ROZKŁAD UZIARNIENIA W GLEBACH RÓŻNYCH KATENACH MORENOWYCH POJEZIERZA MAZURSKIEGO}

Celem niniejszej pracy było porównanie rozkładu uziarnienia w glebach dwóch katen występujących w dwóch mezoregionach Pojezierza Mazurskiego i dwóch fazach zlodowacenia Wisły. Badane kateny zlokalizowane zostały na Pojezierzu Olsztyńskim w fazie pomorskiej (katena Pierwągi) i na Pojezierzu Mrągowski w fazie poznańskiej (katena Linowo). Gleby charakteryzowały się swoistą sekwencją: Haplic Cambisol (Eutric) - Mollic Gleysol (Colluvic) - Umbric Gleysol - Limnic Sapric Histosol. W 34 próbkach glebowych pobranych z poziomów genetycznych oznaczono skład granulometryczny i wyliczono wskaźniki sedymentacyjne i granulometryczne.

Gleby analizowanych dwóch katen charakteryzowały się jednolitym uziarnieniem gliny piaszczystej. Wśród frakcji granulometrycznych dominował piasek drobny i bardzo drobny. $\mathrm{W}$ poziomach powierzchniowych badanych gleb stwierdzono przemieszczanie $\mathrm{w}$ dół stoku frakcji 
pyłowej. Gleby występujące w obniżeniach zawierały o $40 \%$ więcej frakcji pyłowej niż gleby na wierzchowinach. Podobnego procesu nie zaobserwowano przypadku frakcji ilastej. Analizowane gleby charakteryzowały się słabym i bardzo słabym wysortowaniem i różnymi środowiskami sedymentacyjnymi. Gleby wytworzone z polodowcowych glin zwałowych charakteryzowały się nieco mniejszą średnią średnicą ziarna (nie przekraczającą $0.051 \mathrm{~mm}$ ) niż gleby wytworzone z osadów deluwialnych. 